\title{
Potamotrygon boesemani (Chondrichthyes: Myliobatiformes: Potamotrygonidae), a new species of Neotropical freshwater stingray from Surinam
}

\author{
Ricardo S. Rosa ${ }^{1}$, Marcelo R. de Carvalho² and Cristiane de Almeida Wanderley ${ }^{1}$
}

Potamotrygon boesemani, new species, is described from the Corantijn river drainage in Surinam. The species has a diagnostic dorsal color pattern formed by deep orange to red ocellated spots of irregular form, encircled by relatively broad black rings. Potamotrygon boesemani is distinguished from other ocellated congeners ( $P$. motoro, $P$. henlei and $P$. leopoldi) by the more intensely colored ocelli, which are usually yellow in the latter species. From $P$. motoro it is also distinguished by the darker dorsal background coloration, by the broader black contour of the dorsal ocelli, and by the irregular form of the ocelli as compared to the more rounded shape in the latter species. From $P$. henlei and $P$. leopoldi, it is distinguished by the lack of ocelli on tail. From the tentatively identified specimen of $P$. ocellata, which also has dark orange ocelli, the irregular contour of the ocelli in the new species is also distinctive. The teeth are relatively smaller and in greater number than in $P$. motoro and $P$. ocellata, with up to 45 rows in the upper jaw.

Potamotrygon boesemani, espécie nova, é descrita da bacia do rio Corantijn, no Suriname. A espécie apresenta um padrão de coloração dorsal formado por ocelos com coloração alaranjada intensa a vermelha, de formato irregular, margeados por anéis pretos e relativamente grossos. Potamotrygon boesemani distingue-se de outras espécies congêneres oceladas $(P$. motoro, $P$. henlei e $P$. leopoldi) pela coloração mais intensa dos ocelos, que são normalmente amarelados nestas últimas espécies. De $P$. motoro, distingue-se também pela coloração de fundo mais escura no dorso, pelo contorno preto mais largo nos ocelos dorsais, e pela forma irregular dos ocelos comparada à forma arredondada em $P$. motoro. De P. henlei e P. leopoldi, distinguese pela falta de ocelos na cauda. Da espécie tentativamente identificada como $P$. ocellata, que também possui ocelos laranja escuro, o contorno irregular dos ocelos também é distintivo. Os dentes são relativamente menores e em maior número que em P. motoro. e P. ocellata, com até 45 fileiras na mandíbula superior.

Key words: Northern South America, Taxonomy, Potamotrygon motoro, Potamotrygon henlei, Potamotrygon leopoldi, Potamotrygon ocellata.

\section{Introduction}

The Potamotrygonidae Garman, 1877 is the only family among extant chondrichthyans which includes all representatives restricted to freshwater environments (Carvalho, 2001; Charvet-Almeida et al., 2002). This group is widely distributed throughout the river systems of South America, and shows its highest species diversity in the Amazon region (Rosa, 1985). The family currently includes 19 to 21 valid spe- cies distributed in three genera, Potamotrygon, Plesiotrygon, and Paratrygon (Rosa, 1985; Compagno, 1999; Carvalho et al., 2003), including a recently described species of Potamotrygon from French Guiana (Deynat, 2006). One undescribed species of Potamotrygon, collected in several localities in Surinam, was recognized in systematic collections (Rosa, 1985: 356, fig. 85, as Potamotrygon sp. B; Carvalho, pers. obs.), and is herein described and compared with congeners.

\footnotetext{
${ }^{1}$ Departamento de Sistemática e Ecologia, CCEN, Universidade Federal da Paraíba, 58059-900 João Pessoa, PB, Brazil, rsrosa@dse.ufpb.br, criswanderley@gmail.com.

${ }^{2}$ Departamento de Zoologia, Instituto de Biociências, Universidade de São Paulo, Rua do Matão, Trav. 14, nº. 101, 05508-900 São Paulo, SP, Brazil, mrcarvalho@ib.usp.br.
} 


\section{Materials and Methods}

Specimens of the new species are deposited in the Nationaal Natuurhistorisch Museum, Leiden (RMNH), and the National Museum of Natural History, Smithsonian Institution, Washington, D.C. (USNM). A total of 14 specimens (six males and eight females) were examined, including embryos, juveniles and adults. Comparative materials are deposited at the Institut Royal des Sciences Naturelles de Belgique, Brussels (IRSNB), Museu Nacional, Rio do Janeiro (MNRJ), Núcleo de Pesquisas em Limnologia, Ictiologia e Aqüicultura, Universidade Estadual de Maringá, Maringá (NUP), and Museu de Zoologia da Universidade de São Paulo, São Paulo (MZUSP). Measurements and counts follow Rosa (1985) and Rosa et al. (1987). Measurements are expressed as percentages of disc width (DW). Broken tails and stings were excluded from length measurements. Spiracle length is measured as the internal aperture of spiracle, obliquely to midline. Observation of skeletal characters, cranial measurements, vertebral and fin-radial counts were made on radiographs. Fin-radial counts were taken bilaterally. Nomenclature of skeletal parts follows Carvalho et al. (2004).

\section{Potamotrygon boesemani, new species} Figs. 1-6, 8

Holotype. USNM 225574 (male, 377 mm DW), Matapi Creek, ca. $1 \mathrm{~km}$ from Corantijn River, Nickerie District, Surinam, $5^{\circ} 00^{\prime} \mathrm{N}$ $57^{\circ} 16^{\prime}$ W, R. Vari et al., 9 Sep 1980. (Figs. 1, 2).
Paratypes. USNM 225216 (female, $153 \mathrm{~mm} \mathrm{DW}$ ), stream about $0.5 \mathrm{~km}$ inland of Camp Mataway, Nickerie District, Surinam, 4 48 'N 57²43'W, Vari et al., 12 Sep 1980; USNM 225575 (male, $250 \mathrm{~mm}$ DW), Corantijn River at km 180, Nickerie District, Surinam, $5^{\circ} 08^{\prime} \mathrm{N}$ $57^{\circ} 18^{\prime} \mathrm{W}$, R. Vari et al., 8 Sep 1980 (Fig. 3); USNM 388849 (male [Fig. 4], $413 \mathrm{~mm}$ DW; female [Fig. 5], $427 \mathrm{~mm}$ DW), same data as holotype.

Non-type specimens. RMNH 26188 (two females, 275 and 364 $\mathrm{mm}$ DW), tributary of Kabalebo river, ca. 8 mi. below Avanavero Falls, Corantijn river drainage, Surinam (Fig. 6); USNM 226191 (male, $128 \mathrm{~mm}$ DW), same data as USNM 225575; USNM 226192 (one male and two female embryos aborted by adult female), same data as USNM 225574; USNM 226193 (two females, 134 and 150 mm DW), stream on south bank of Lucie River, ca. $6 \mathrm{~km}$ upstream of ferry crossing on Amotopo-Camp Geol. Rd., Corantijn drainage, Nickerie District, Surinam, $3^{\circ} 36^{\prime} \mathrm{N} 57^{\circ} 37^{\prime} \mathrm{W}$, R. Vari et al., $18 \mathrm{Sep}$ 1980; USNM 226194 (male, 163 mm DW), small creek entering Corantijn river on east side approximately $300 \mathrm{~m}$ North of Amotopo Boat Landing, Nickerie District, Surinam, $3^{\circ} 33^{\prime}$ N $57^{\circ} 40^{\prime} \mathrm{W}$, R. Vari et al., 19 Sep 1980.

Diagnosis. Dorsal region of disc of dark brown background coloration, with deep orange to red ocellated spots of irregular form, encircled by relatively broad black rings, in irregular concentric series, and frequently in pairs around disc center; buccal cavity dark-pigmented with orange spots in adult specimens. This species is distinguished from the ocellated congeners $P$. motoro (Natterer in Müller \& Henle), $P$. henlei (Castelnau), and $P$. leopoldi Castex \& Castello by the more intensely colored ocelli, which are usually yellow in the latter species. From P. motoro, it is also distinguished by the darker

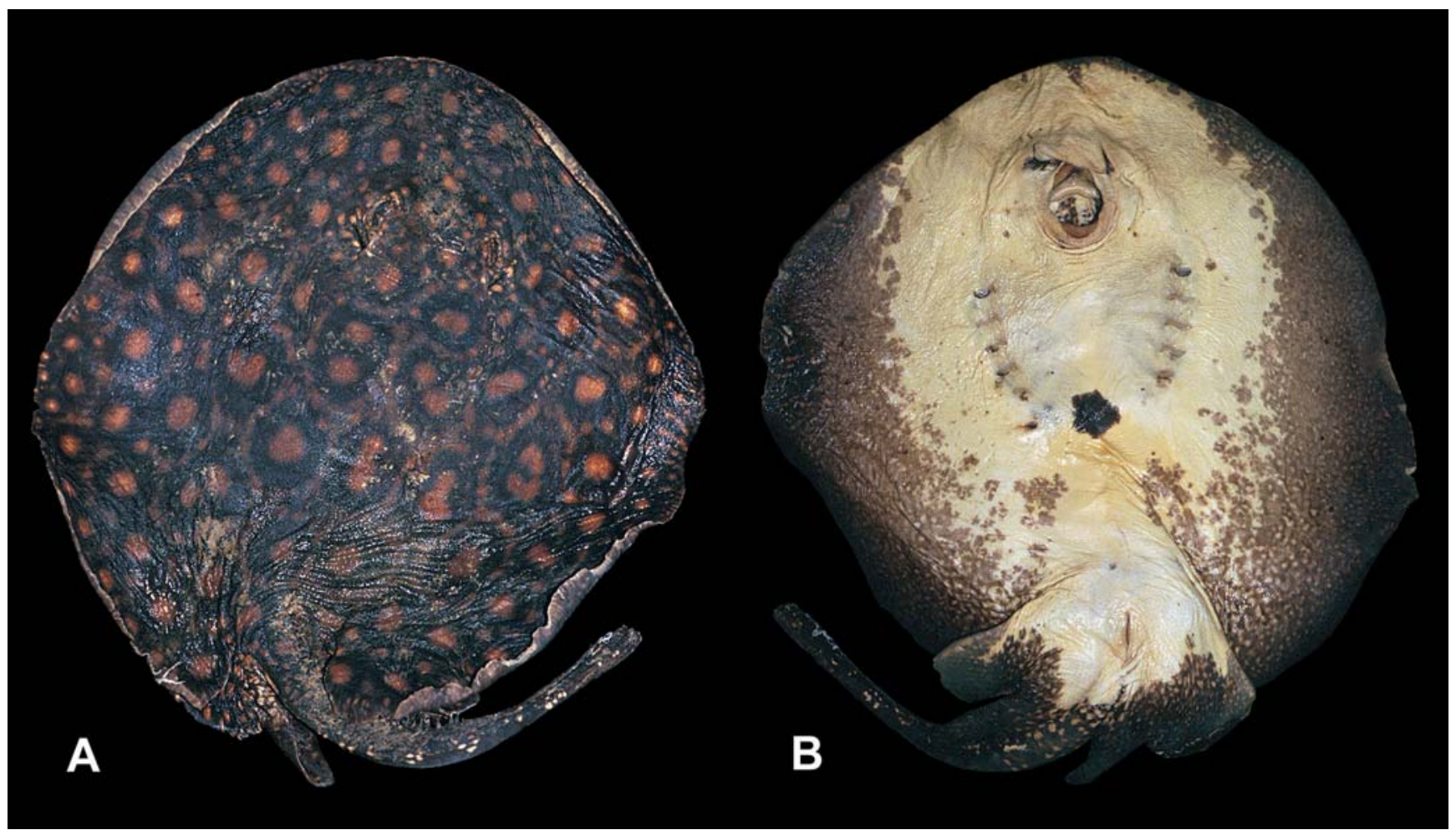

Fig. 1. Potamotrygon boesemani. Dorsal (A) and ventral (B) views of holotype (USNM 225574, 377 mm DW), Corantijn river. 

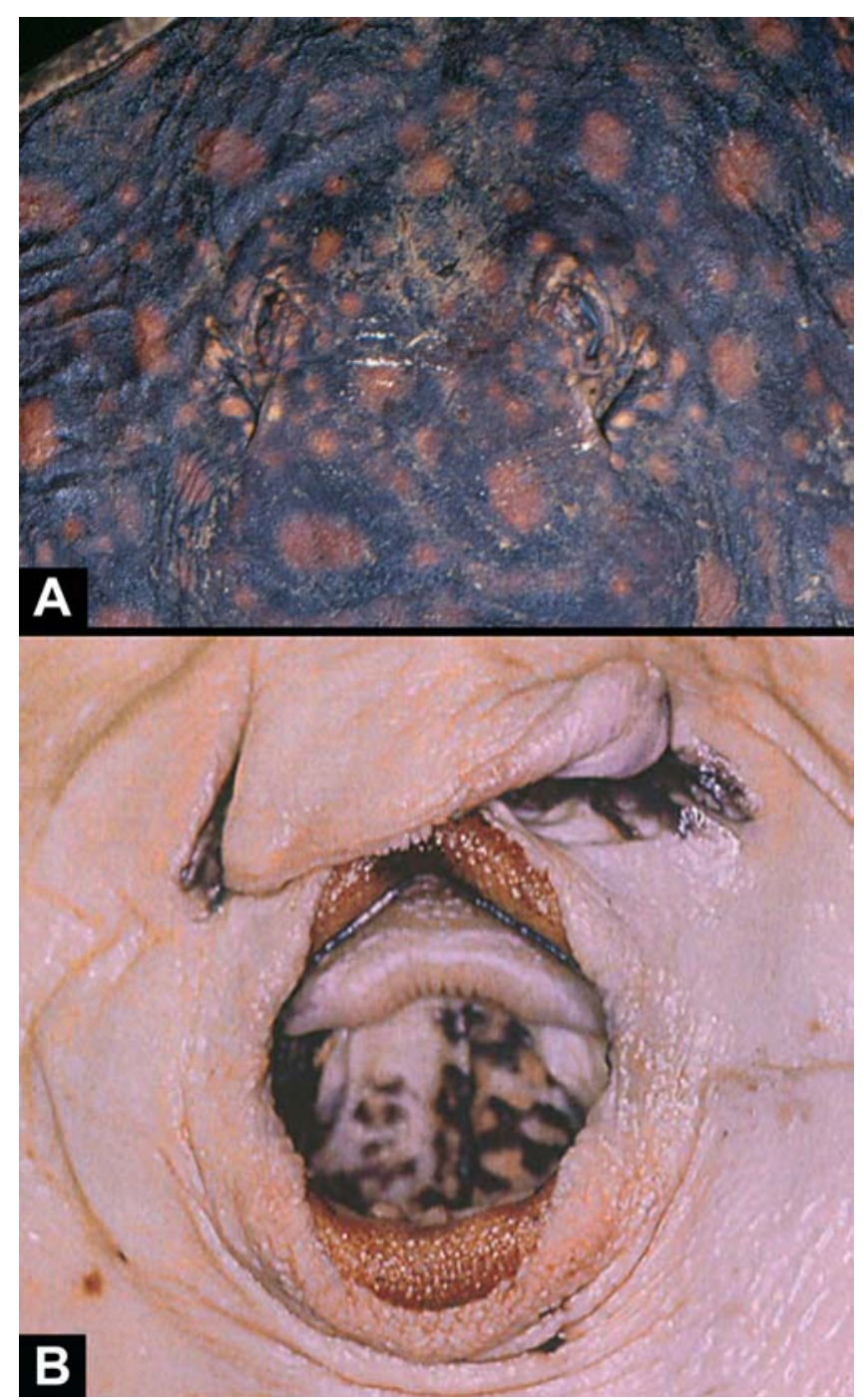

Fig. 2. Potamotrygon boesemani. Detailed view of interorbital region (A) and of mouth and nasal cavity (B) of holotype (USNM 225574, $377 \mathrm{~mm} \mathrm{DW).}$

dorsal background coloration, by the broader black contour of the dorsal ocelli, and by the irregular form of the ocelli as compared to the rounded shape in the latter species. From $P$. henle $i$ and $P$. leopoldi, it is distinguished by the lack of ocelli on tail. From the tentatively identified specimen of $P$. ocellata (Engelhardt), which also has dark orange ocelli, the irregular contour of the ocelli in the new species is also distinctive. The teeth are relatively smaller and in greater number (up to 45 rows in the upper jaw) than in P. motoro (23 to 32 ) and $P$. ocellata (24 in specimen $190 \mathrm{~mm} \mathrm{DW}$ ). The number of pectoral-fin radials (98 to 104) is also slightly higher than in $P$. ocellata (94).

Description. Measurements are given in Table 1 and counts in Table 2. Disc subelliptic, disc length 1.02-1.17 times its width. Tail flattened dorsoventrally, tail length 0.9-1.3 times DW in intact specimens. Dorsal surface of disc rough in adults,

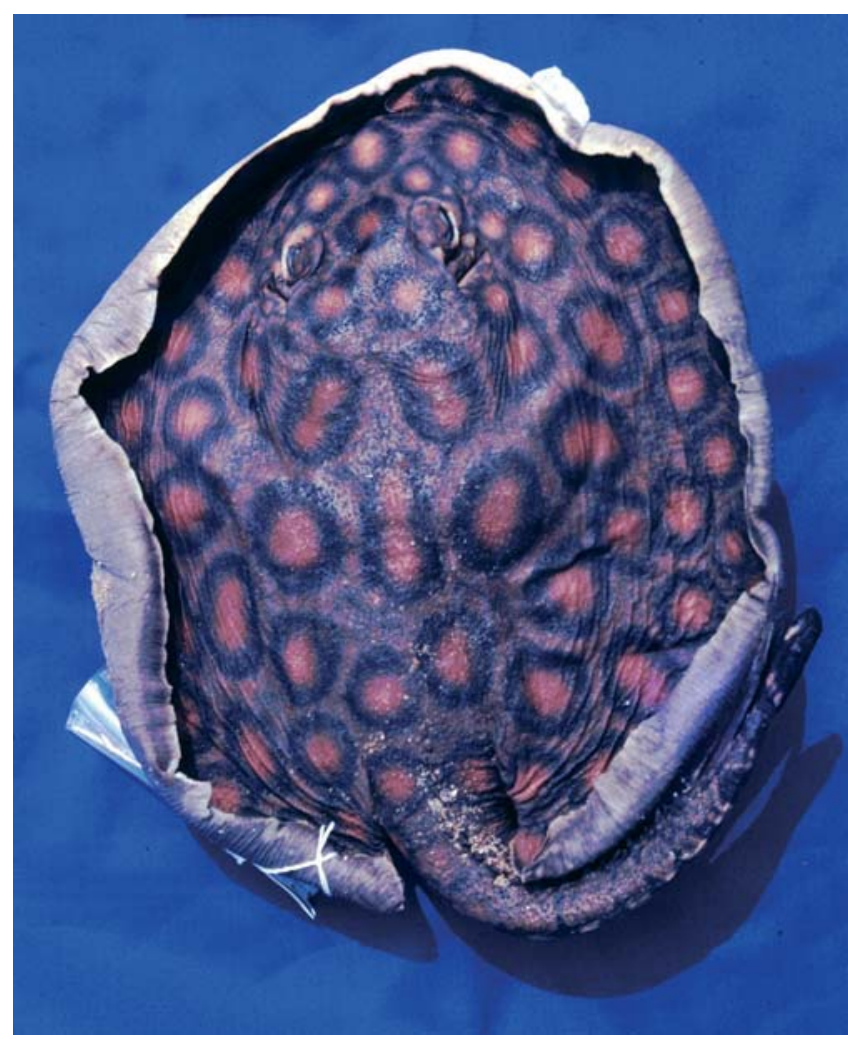

Fig. 3. Potamotrygon boesemani. Dorsal view of paratype (USNM 225575, $250 \mathrm{~mm}$ DW), from Corantijn river.

with denticles more developed and concentrated on midline and anterior portion. Tail with 12-27 median dorsal spines in young specimens and 28-42 in adults, in irregular rows; tail spines relatively high, acute and less curved when compared with congeners. Tail with well-developed lateral spines in adults, shorter than dorsal spines. One or two serrated caudal stings, inserted relatively close to tail base; sting length 1.6 to 2.5 times tail width. Eyes relatively large, eye length 1.62.9 in interorbital distance, 3.5-6.4 in interocular distance. Spiracle length 1.4-2.1 times eye length, 2.0-3.4 in interspiracular distance. Mouth with five buccal papillae in all specimens; mouth width 9.2-13.6 in DW, 0.8-1.1 times internarial width. Teeth relatively small, set in quincunx, in 24 to 45 longitudinal rows in upper jaw, 24 to 43 in lower jaw, 5 to 10 exposed teeth in median row of lower jaw. Tooth rows increase in number with body size (Fig. 7). Teeth sexually dimorphic, females and immature males with rhombic posterior margin, mature males with cuspidate posterior margin. Nostrils oblique to midline, nostril length 1.2-1.6 ( $\mathrm{x}=1.4)$ in internarial distance, 2.3-2.9 $(\mathrm{x}=2.6)$ in prenarial distance. Branchial basket relatively broad, its greatest width at level of first pair of gill openings 3.6-4.2 in DW.

Neurocranium (Fig. 8) relatively long, cranium length 26.7$27.7 \% \mathrm{DW}(\mathrm{x}=27.3, \mathrm{n}=5, \mathrm{SD}=0.4)$. Nasal capsules anteriorly convex with a median concavity between them; cranium width at nasal capsules $17.0-18.0 \% \mathrm{DW}(\mathrm{x}=17.5, \mathrm{n}=5, \mathrm{SD}=0.4)$. Preorbital processes laterally prominent and subtriangular; cra- 


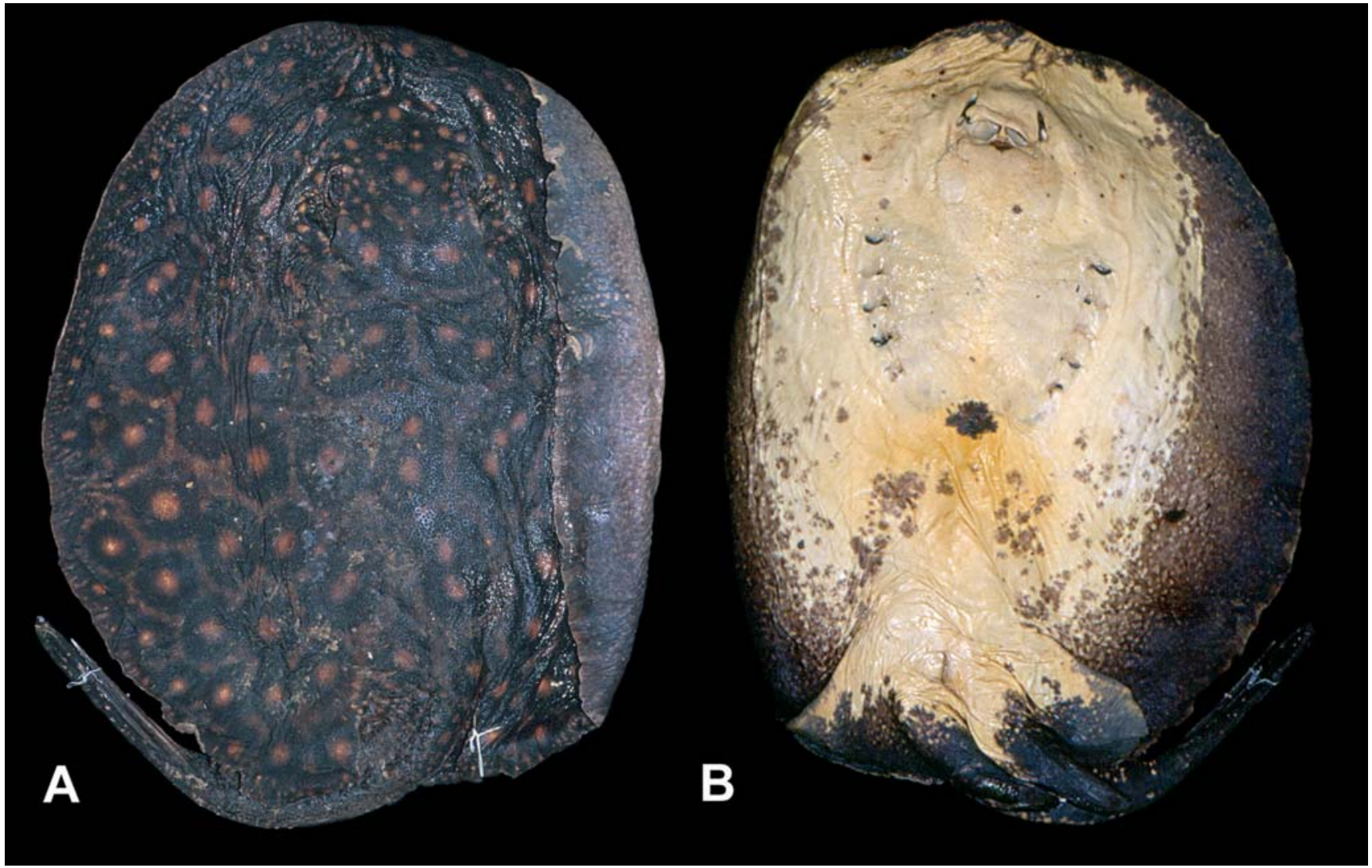

Fig. 4. Potamotrygon boesemani. Dorsal (A) and ventral (B) views of paratype (USNM 388849, male, 413 mm DW), from Corantijn river.

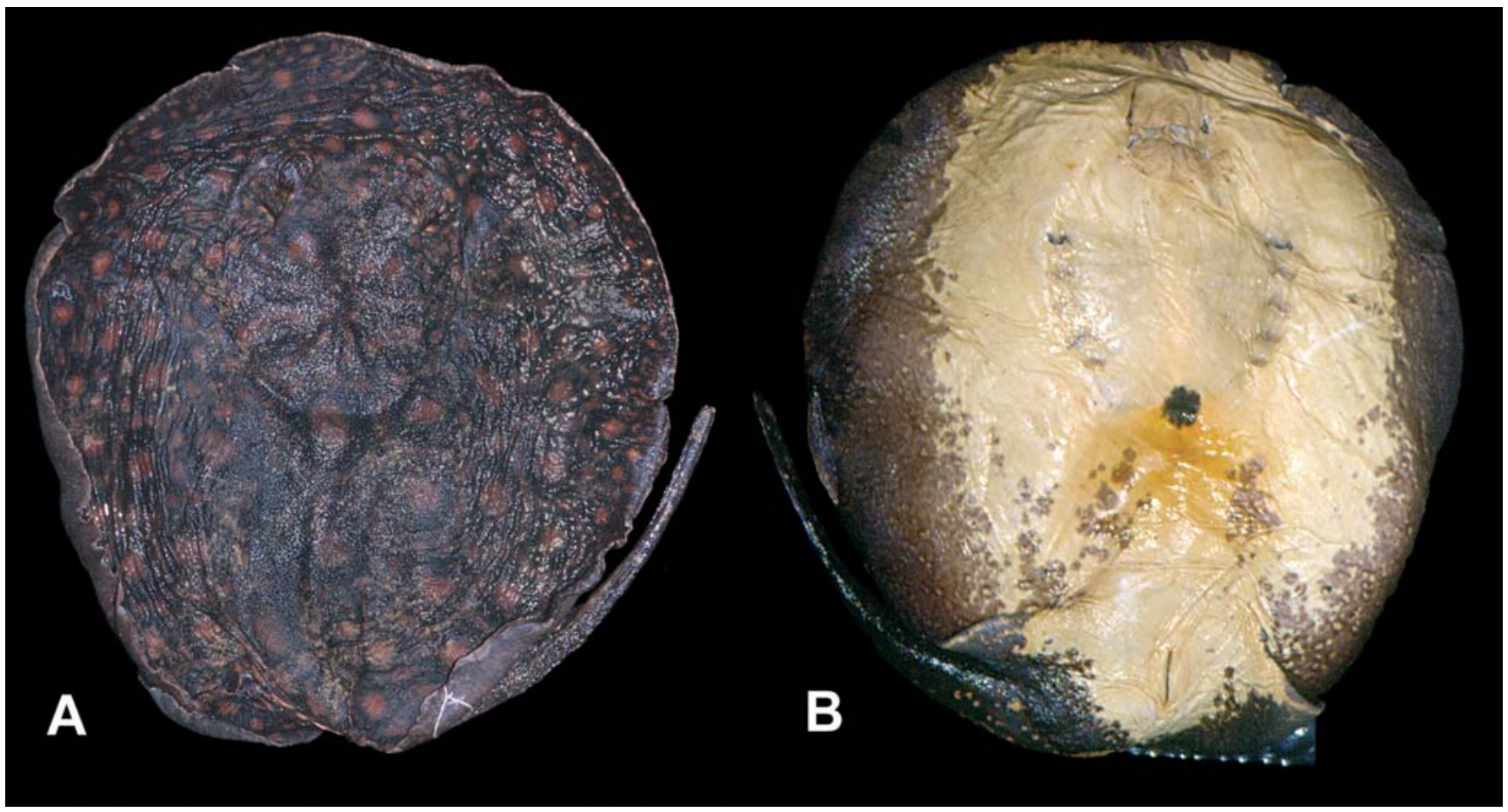

Fig. 5. Potamotrygon boesemani. Dorsal (A) and ventral (B) views of paratype (USNM 388849, female, $427 \mathrm{~mm}$ DW), from Corantijn river. 
nium width at preorbital processes $18.9-21.6 \% \mathrm{DW}(\mathrm{x}=20.3$, $\mathrm{n}=5, \mathrm{SD}=1.0$ ). Supraorbital processes short; cranium width at supraorbital processes 9.8-10.4\% DW ( $\mathrm{x}=10.1, \mathrm{n}=4, \mathrm{SD}=0.3)$. Postorbital processes laterally expanded and flattened; cranium width at postorbital processes $20.2-22.0 \% \mathrm{DW}$ ( $\mathrm{x}=21.2$, $\mathrm{n}=3$ ). Cranial fontanelle elongate and anteriorly broad, with slight constriction between precerebral and frontoparietal portions; fontanelle length 16.6-17.9\% DW ( $x=17.1, n=5$, $\mathrm{SD}=0.5)$, fontanelle width 6.6-9.2\% DW $(\mathrm{x}=7.7, \mathrm{n}=5, \mathrm{SD}=1.1)$. Antorbital cartilage triangular and elongated, tapering towards posterior end (Fig. 8b). Upper jaws (palatoquadrates) slender and separated at symphysis. Lower jaws (Meckel's cartilages) broad, stout and separated at symphysis; distance between lateral margins of lower jaws nearly equal to preorbital width of cranium. Hyomandibular cartilage slender and slightly arched at its anterior end. Two parallel angular cartilages at the articulation of hyomandibular cartilage and lower jaw. Claspers relatively long, clasper length in immature specimens 8.6 to 13.3 in DW, clasper length in adults $3.6-3.7$ in DW.

Color in alcohol. Dorsal surface of disc with dark brown background coloration and deep orange to red ocellated spots of irregular format, surrounded by thick black rings. Black ring width usually equal to or larger than diameter of corresponding ocellus. Some ocelli with light yellow center, gradually darkening to orange towards margin. Some ocelli joined in pairs, mainly in disc center, where they are more irregularly shaped. Ocelli diminish in size towards disc margins. Dorsal surface of pelvic fins with same color as disc, bearing smaller
Table 1. Proportional measurements on specimens of Potamotrygon boesemani, as percent of disc width. Asterisks indicate the broken tail of the holotype $(\mathrm{H})$.

\begin{tabular}{lccccc}
\hline & $\mathrm{H}$ & $\mathrm{n}$ & Range & Mean & $\mathrm{SD}$ \\
\hline Disc width (100\%) & 377 & 13 & $87-427$ & & \\
Disc length & 110 & 13 & $102.2-117.1$ & 108.41 & 4.39 \\
Total length & $*$ & 4 & $201.5-219.5$ & 210.30 & 7.51 \\
Disc length to axil of pectoral fin & 95.4 & 13 & $86.3-105.1$ & 93.99 & 5.16 \\
Preoral length & 19.1 & 13 & $19.1-24.5$ & 21.85 & 1.72 \\
Mouth to scapulocoracoid & 34.7 & 13 & $30.5-37$ & 33.25 & 2.18 \\
Mouth to cloaca & 65.5 & 13 & $60.5-70.8$ & 64.63 & 2.73 \\
Snout to cloaca & 85.6 & 13 & $80.1-92.6$ & 86.02 & 3.95 \\
Cloaca to sting base & 39.7 & 12 & $37.5-50.4$ & 41.91 & 3.50 \\
Tail length & $*$ & 5 & $91.5-128.7$ & 112.88 & 13.93 \\
Sting length & 23.2 & 12 & $16.5-26$ & 22.17 & 3.32 \\
Tail width at base & 10.6 & 13 & $8.9-13.2$ & 10.82 & 1.09 \\
Tail width at insertion of sting & 5.2 & 13 & $5-7.3$ & 5.93 & 0.64 \\
Tail height at base & 5.7 & 13 & $5-8.8$ & 6.61 & 1.13 \\
Pelvic fin anterior margin & 25.4 & 13 & $22.4-30.5$ & 27.02 & 2.61 \\
Pelvic fin posterior margin & 26.5 & 13 & $18.7-27.1$ & 22.52 & 2.50 \\
Clasper length from cloaca & 27.5 & 6 & $7.5-27.5$ & 15.57 & 9.11 \\
Eye diameter & 3.6 & 13 & $3.1-6.3$ & 4.66 & 1.09 \\
Spiracle length & 6.4 & 13 & $5.9-12$ & 8.05 & 1.69 \\
Preocular distance & 26.6 & 13 & $25.5-29.9$ & 25.31 & 7.72 \\
Interorbital distance & 9.0 & 12 & $8.8-11.2$ & 10.08 & 0.89 \\
Interocular distance & 19.0 & 13 & $18.4-28.2$ & 21.58 & 2.72 \\
Interspiracular distance & 20.1 & 13 & $19-24$ & 20.93 & 1.31 \\
Internarial distance & 9.0 & 13 & $7.2-9.5$ & 8.72 & 0.60 \\
Mouth width & 8.3 & 13 & $7.3-10.9$ & 8.75 & 0.86 \\
Nostril length & 5.7 & 11 & $5.6-7.5$ & 6.25 & 0.70 \\
Distance between first pair of gill & 26.3 & 13 & $23.5-27.9$ & 26.02 & 1.39 \\
slits & & & & \\
Distance between first and fifth & 15.5 & 13 & $14.5-17.6$ & 16.22 & 0.94 \\
gill slits & & & & & \\
Upper dental plate width & 7.8 & 10 & $5.2-8.5$ & 7.78 & 0.96 \\
Lower dental plate width & 6.6 & 10 & $5.2-8.2$ & 7.31 & 0.89 \\
\hline & & & & & \\
& & & &
\end{tabular}
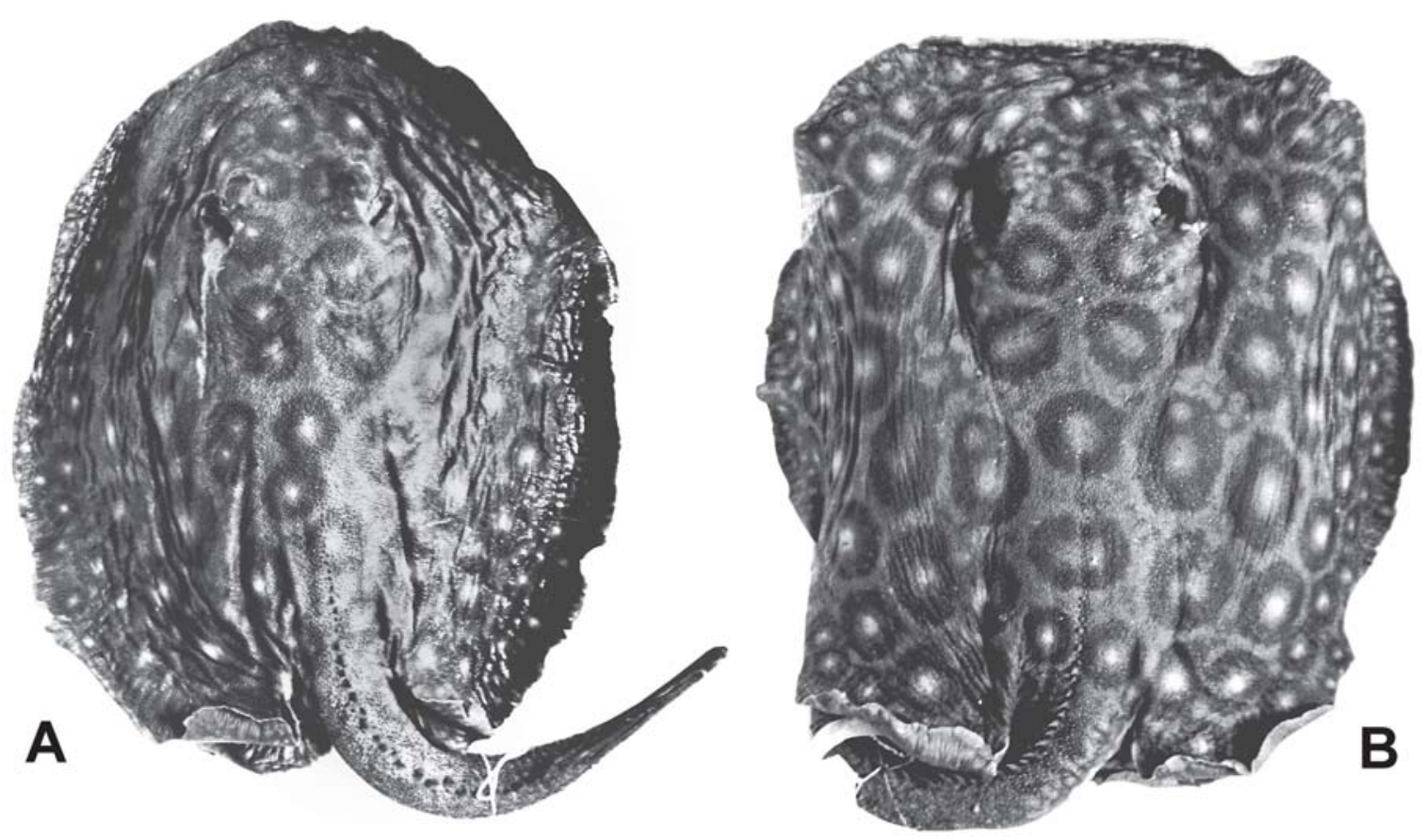

Fig. 6. Potamotrygon boesemani. Dorsal views of non-type specimens (RMNH 26188), from Corantijn river: (A) 275 mm DW; (B) $364 \mathrm{~mm} \mathrm{DW}$. 


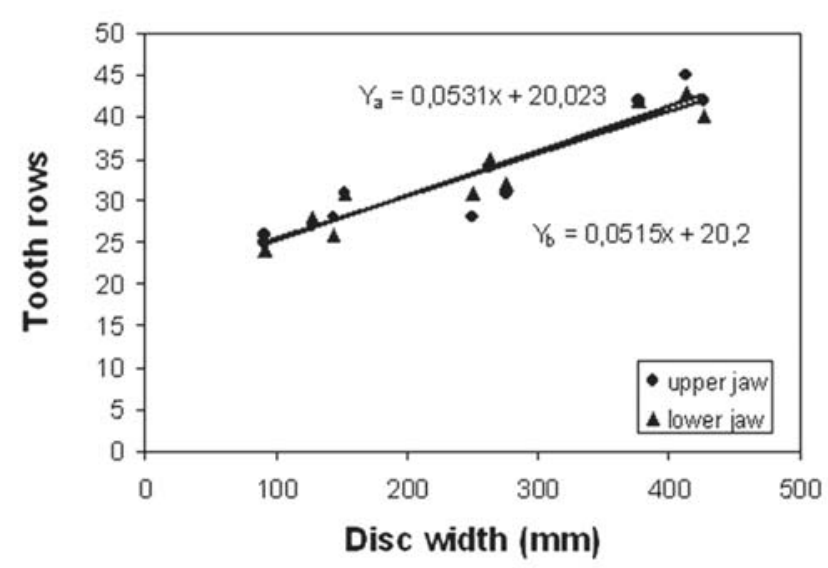

Fig. 7. Number of longitudinal tooth rows in upper (a) and lower (b) jaws of Potamotrygon boesemani, relative to disc width. Adjusted straight lines of both regression functions nearly coincident.

orange ocelli and irregular lighter spots. Ventral surface of disc medially white and laterally with broad areas pigmented in dark brown, with scattered ocellated or vermiculated spots, ranging from light yellow to orange. Ventral disc surface of adult specimens usually with one central dark spot over pectoral girdle. Embryos and young specimens with completely creamy white ventral surface. Tail dark brown dorsally, with irregular orange spots but no large ocelli beyond its base. Lateral surface of tail with alternate black bars with white spots in the interspaces. Spiracular cavity, floor and ceiling of mouth cavity pigmented with dark and orange spots in adult specimens. Holotype with dark pigment also in nasal cavity (Fig. 2b). The coloration of preserved specimens does not differ significantly from freshly collected material, as confirmed by color slides taken in the field shortly after capture.
Table 2. Counts on specimens of Potamotrygon boesemani.

\begin{tabular}{lccccc}
\hline & Holotype & $\mathrm{n}$ & Range & Mean & $\mathrm{SD}$ \\
\hline propterygial radials & $46-47$ & 6 & $44-47$ & 45.3 & 1.2 \\
mesopterygial radials & $16-16$ & 6 & $14-19$ & 16.5 & 1.4 \\
metapterygial radials & $38-38$ & 6 & $37-41$ & 38.7 & 1.2 \\
total pectoral-fin radials & $100-101$ & 6 & $98-104$ & 100.5 & 1.6 \\
pelvic-fin radials (? ) & $20-20$ & 3 & $20-22$ & 21 & 0.8 \\
pelvic-fin radials (? ) & - & 3 & $24-27$ & 25.1 & 1.1 \\
precaudal vertebrae & 27 & 6 & $27-30$ & 28.1 & 0.9 \\
caudal vertebrae & 92 & 6 & $92-101$ & 97.5 & 3.2 \\
caudal vertebrae to insertion & 72 & 6 & $63-73$ & 69.2 & 3.6 \\
$\quad$ of sting & & & & & \\
total vertebrae & 119 & 6 & $119-129$ & 125.7 & 3.5 \\
diplospondylous centra & - & 2 & $0-12$ & - & - \\
centra in posterior synarcual & 2 & 6 & $2-4$ & 3.0 & 0.6 \\
\hline
\end{tabular}

Geographic Distribution. This species is known from the Corantijn river drainage, in Sipaliwini and Nickerie districts, Surinam (Fig. 9).

Etymology. The specific name honors the late Dutch biologist Marinus Boeseman (1916-2006), who contributed substantially to our knowledge of both South American ichthyology (including chondrichthyans) and zoological history.

\section{Discussion}

The USNM specimens of Potamotrygon boesemani had been misidentified as Potamotrygon histrix in museum labels. As pointed out by Rosa (1985), the type series of Potamotrygon histrix by Müller and Henle (1841) consisted of heterogenous material from Argentina, Surinam and Venezuela, of which only the first should retain type status. Potamotrygon histrix is considered endemic to the ParanáParaguay river drainages, and the many citations of the spe-

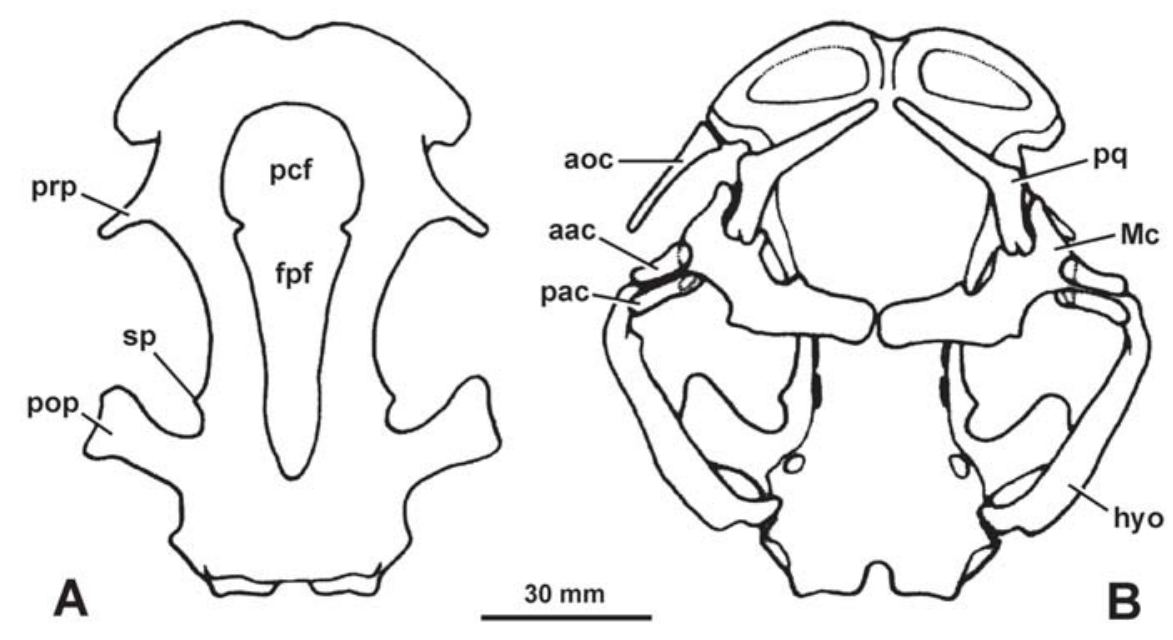

Fig. 8. Potamotrygon boesemani. (A) Dorsal view of neurocranium. (B) Ventral view of neurocranium and jaws, traced from radiograph (Meckel's cartilage and palatoquadrate somewhat distorted by opened mouth) (USNM 225574, $377 \mathrm{~mm}$ DW). Note that antorbital cartilage has been removed from left side in $\mathbf{B}$. Abbreviations: aac $=$ anterior angular cartilage, $\mathbf{a o c}=$ antorbital cartilage, $\mathbf{f p} \mathbf{f}=$ frontoparietal fontanelle, hyo=hyomandibula, $\mathbf{M c}=$ Meckel's cartilage, pac=posterior angular cartilage, $\mathbf{p c f}=$ precerebral fontanelle, $\mathbf{p o p}=$ postorbital process, $\mathbf{p q}=$ palatoquadrate, $\mathbf{p r p}=$ preorbital process, $\mathbf{s p}=$ supraorbital process . 


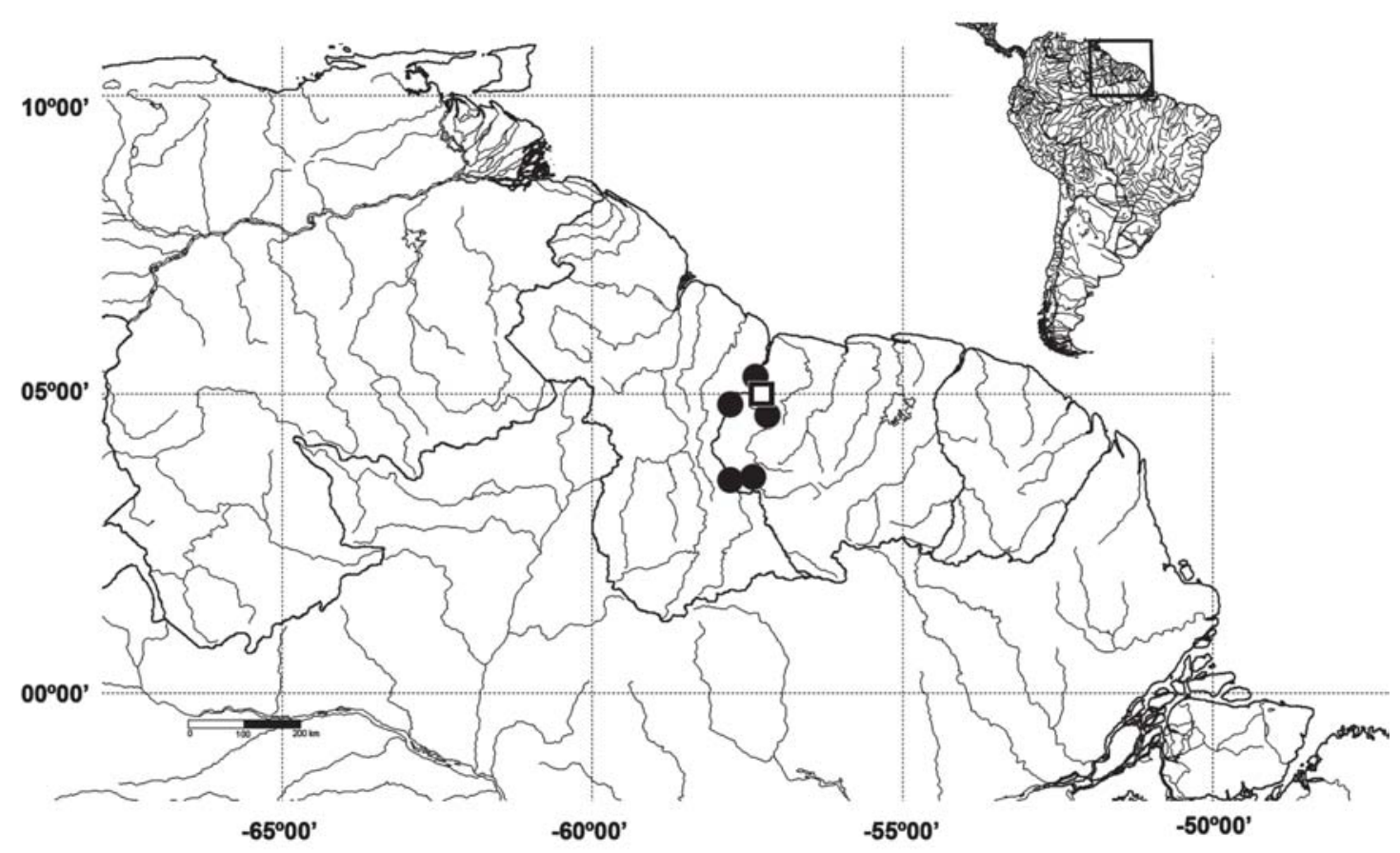

Fig. 9. Map depicting localities of specimens of Potamotrygon boesemani. Open square is the locality of holotype (Corantijn river).

cies outside this range possibly represent misidentifications or compilations based on the erroneous geographic range given in the original description. In any event, none of the specimens from Surinam and Venezuela in the type series of $P$. histrix correspond with the species described herein, the former being identified as Potamotrygon orbignyi and the latter as Potamotrygon yepezi (Rosa, 1985).

Taxonomic distinction of the species of Potamotrygon has been based mostly on color pattern, and this was the character that led to the recognition of this new species. On the other hand, the existence of several species of the genus with similar ocellated or reticulated color patterns, in addition to the extreme intraspecific variation of coloration present in many species, has resulted in several instances of the two most common yet contrasting errors in taxonomy-unjustified synonymies and overlooked species. The current trend of using the phylogenetic species concept should improve the overall taxonomic picture of the Potamotrygonidae, especially upon the revision of taxa such as $P$. motoro and $P$. orbinyi which, according to their cited geographic distribution, clearly represent species complexes and not single species.

Comparisons of the new species with the taxon tentatively identified as $P$. ocellata by Rosa (1985, based on specimen MNRJ 10620) are currently precluded by the lack of additional specimens of the latter. Potamotrygon ocellata was described by Engelhardt (1912) as a subspecies of Trygon hystrix (= Potamotrygon histrix) from the mouth of the Amazon river (Ilha Mexiana, Brazil). The type specimen is considered lost due to World War II (see Neumann, 2006), but the mention of deep orange to rusty red irregular spots dorsally on disc in the original description indicates its similarity with Potamotrygon boesemani. Specimen MNRJ 10620, from Macapá (Amapá state, Brazil), shows relatively larger teeth, fewer tooth rows and fewer pectoral-fin radials (94) when compared with specimens of Potamotrygon boesemani. Furthermore, the two forms are geographically isolated by several coastal drainages in Amapá and French Guiana.

\section{Acknowledgements}

We are indebted to the late M. Boeseman, Martin van Oijen and Hans Tegelaar (RMNH), J. -P. Gosse, Guy Lenglet and Louis Walschaerts (IRSNB), Richard Vari, Stanley Weitzman, Lynne Parenti, Leslie Knapp and Jerry Finnan (USNM), and José Lima de Figueiredo, Osvaldo Oyakawa and Naércio Menezes (MZUSP) for their assistance during several visits of the first and second authors to their institutions. Jeff Williams and Shirleen Smith provided additional information regarding USNM specimens. Richard Vari (USNM) provided a slide of a freshly captured specimen of the new species. Thiago Loboda generously provided original data on Potamotrygon motoro for comparisons, and Carla S. Pavanelli and Weferson J. da Graça (NUP) provided specimens of $P$. motoro for study. Alexandre Ribeiro and Aléssio Datovo assisted with some of the figures. Financial support to the second author related to this study was provided by grants from the Conselho Nacional de Desenvolvimento Científico e Tecnológico $(\mathrm{CNPq})$, Fundação de Amparo à Pesquisa do Estado de São Paulo (02/06459-0) and by travel 
grants from the USNM. Part of this study was done during the doctoral research of the first author, supported by Coordenação de Aperfeiçoamento de Pessoal de Nível Superior (CAPES) and the Virginia Institute of Marine Science. $\mathrm{CNPq}$ also provided research grants to the first and third authors.

Comparative material. Potamotrygon henlei: MZUSP 14768 (female), Marabá, rio Itacaiúnas, PA, Brazil. Potamotrygon leopoldi: IRSNB 23936 (male, holotype), rio Xingú, downstream of the confluence with rio Auaia-Missú, MT, Brazil; MZUSP 35986 (female), rio Fresco, Aldeia Gorotire, São Félix do Xingú, PA, Brazil. Potamotrygon motoro: MZUSP 14856 (male), Restinga de Taiamã, rio Paraguai; NUP 2106 (female), rio Cuiabá, município de Chapada dos Guimarães, MT, Brazil, $14^{\circ} 41^{\prime}$ S, 56 $6^{\circ} 15^{\prime}$ W; NUP 2969 (female), reservatório Manso, rio Manso, município de Chapada dos Guimarães, MT, Brazil; NUP 3428 (female), Baia Sinhá Mariana, tributary to rio Cuiabá, Município de Barão de Melgaço, MT, Bra-

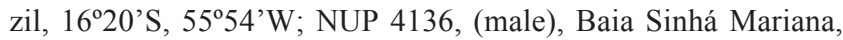
tributary to rio Cuiabá, município de Barão de Melgaço, MT, Brazil, 16020'20.5'S, 54 54'10.3'W. Potamotrygon cf. ocellata: MNRJ 10620 (female), rio Pedreira, Macapá, Amapá, Brazil.

\section{Literature Cited}

Carvalho, M. R. de. 2001. Freshwater stingrays from South America (review). Copeia, 2001(4): 1167-1169.

Carvalho, M. R. de, J. G. Maisey \& L. Grande. 2004. Freshwater stingrays of the Green River Formation of Wyoming (Early Eocene), with the description of a new genus and species and an analysis of its phylogenetic relationships (Chondrichthyes: Myliobatiformes). Bulletin of the American Museum of Natural History, 284: 1-136.
Carvalho, M. R. de, N. R. Lovejoy \& R. S. Rosa. 2003. Potamotrygonidae. Pp. 22-29. In: Reis, R. E., C. J. Ferraris Jr. \& S. O. Kullander (Eds.). Checklist of freshwater fishes of South and Central America. Porto Alegre, EDIPUCRS, 729 p.

Charvet-Almeida, P., M. L. G. Araújo, R. S. Rosa \& G. Rincón. 2002. Neotropical freshwater stingrays: diversity and conservation status. Shark News, 14: 1-2.

Compagno, L. J. V. 1999. Checklist of living elasmobranchs. Pp. 471-498. In: Hamlett, W. C. (Ed.). Sharks, skates and rays, the biology of elasmobranch fishes. Baltimore, The John Hopkins University Press, 515p.

Deynat, P. 2006. Potamotrygon marinae n. sp., une nouvelle espèce de raies d'eau douce de Guyane (Myliobatiformes, Potamotrygonidae). Comptes Rendus Biologies, 329(2006) 483493.

Engelhardt, R. 1912. Uber einige neue Selachier-Formen. Zoologischer Anzeiger, 39(21/22): 643-648.

Müller, J. \& F. G. J. Henle. 1841. Systematische beschreibung der Plagiostomen. Berlin, Verlag von Veit.

Neumann, D. 2006. Type Catalogue of the Ichthyological Collection of the Zoologische Staatssammlung München. Part I: Historic type material from the "Old Collection", destroyed in the night 24/25 April 1944. Spixiana, 29(3): 259-285.

Rosa, R. S. 1985. A systematic revision of the South American freshwater stingrays (Chondrichthyes: Potamotrygonidae). Unpublished Ph.D. Dissertation, The College of William and Mary, Williamsburg, Virginia, 523p.

Rosa, R. S., H. P. Castello. \& T. B. Thorson. 1987. Plesiotrygon iwamae, a new genus and species of Neotropical freshwater stingray (Chondrichthyes: Potamotrygonidae). Copeia, 1987 (4): 447-458.

Accepted February 2008 Published 31 March 2008 